\title{
The Historical Evolution and Contemporary Value of Craftsmanship Spirit in Vocational College
}

\author{
Tian $\mathrm{Yu}^{1,{ }^{*}}$ Hui Shen ${ }^{1} \mathrm{Hui} \mathrm{Li}^{1}$ \\ ${ }^{1}$ Chengdu Vocational \&Technical College of Industry, Chengdu, Sichuan 610218, China \\ *Corresponding author. Email: 278050545@qq.com
}

\begin{abstract}
The craftsmanship spirit has a long history in Chinese traditional culture. With the development of vocational education in China, the craftsmanship spirit has gone through four stages of depression, exploration, development and revival in vocational colleges. Inheriting and innovating the craftsmanship spirit is an inevitable choice for the reform and development of vocational colleges, and its value is becoming increasingly prominent in providing high-quality technical and skilled personnel for the construction of a "manufacturing power". Therefore, vocational colleges should pay attention to the construction of the craftsman spirit cultivation curriculum system, strengthen industryeducation integration and school-enterprise cooperation, and build a campus culture with the craftsmanship spirit as the main line.
\end{abstract}

Keywords: craftsmanship spirit, vocational college, evolution, path

\section{INTRODUCTION}

The "Craftsmanship Spirit" has a long history in Chinese traditional culture. The depiction of ancient craftsmen and the description of the spirit of traditional craftsmen are reflected in the ancestors of Chao (the founder of the house) and Sui-Ren Shi (the first one made the fire) from Han Feizi, "Five emphasizes", "dismember an ox as skillfully as a butcher "from Chuang-tzu," to help each other in study "from The Book of Songs, and "the old man selling oil" from Ouyang Xiu in the Northern Song Dynasty. In 2016, the government work report first advocated "Craftsmanship Spirit". In 2017, the report of the 19th National Congress of the Communist Party of China put forward "building a knowledge-based, skilled and innovative workforce, promoting the spirit of model workers and craftsmanship spirit", making "Craftsmanship Spirit" become a research hotspot. Vocational colleges shoulder the heavy responsibility of delivering technical and technical talents to the front line of production and construction. Carrying forward and cultivating craftsmanship spirit is both a historical mission and a realistic need.

*Funds: Financed by Chengdu Key Research Base of Philosophy and Social Sciences - Chengdu Craftsman Culture Research Center 2020 Project "Research on the Historical Evolution and Contemporary Value of Craftsmanship Spirit in Vocational Colleges" (2020ZC11); Sichuan Educational Science and Research Institute 2020 Sichuan Educational Research Funding Project "Research on the Inheritance and Innovation of Craftsmanship Spirit in Vocational Colleges".

\section{THE COUPLING OF CRAFTSMANSHIP SPIRIT AND TALENT CULTIVATION IN VOCATIONAL COLLEGE}

"Craftsmanship Spirit" has expanded from the original value concept of the unity of truth, goodness, beauty and ingenuity pursued by craftsmen to the pursuit of professional attitude and behavior of workers in various industries who strive for excellence, patience, meticulous, dedication and innovation. Whether it is the inheritance of cultivation methods or the pursuit of sustainable development, craftsmanship spirit and talent training in vocational colleges are highly coupled.

\section{A. Vocational colleges are the inheritance for the cultivation mode of craftsmanship spirit}

Craftsmanship spirit originates from traditional handicraft industry, which can be traced back to the intergenerational inheritance mode marked by "fatherson transmission" in family workshops. With the differentiation of industries, the demand of rival industrialists has increased, and family workshops have begun to recruit apprentices with foreign names. The education mode of "mentoring and apprenticeship" has become the main training mode for craftsmen and artists. In addition to the acquisition of technology, the teaching process also includes the cultivation of morality and spirit [1]. In the industrial age, the traditional handicraft industry was replaced by the mechanized mass production, and the market demand for finely crafted craftsmen changed to the demand for 
assembly line workers who operated machines. Schools in the form of vocational education came into being, replacing handicraft workshops as the main way to cultivate "new craftsmen" in large quantities.

\section{B. Craftsmanship spirit is an important support for vocational colleges to realize their own development}

Vocational colleges cultivate technical talents for economic and social development, which determines that they must be market-oriented. However, if they only pay attention to market demand and neglect students' personal development, just like producing screws fixed in a certain link, which only pays attention to the number and speed of students becoming workers, and lack of high-standard skills and professional spirit requirements, it will directly lead to inferior product quality and ultimately fail to meet market demand. This is the case with vocational education in the early industrial age. German manufacturing products were resisted by other countries because of their inferior quality, and then the "Duales Studium" vocational education reform was carried out on a large scale. The dual subjects of schools and enterprises cultivated students, jointly formulated the training objectives and contents, and ensured that the talents had the skills standards and professional qualities of the corresponding posts through examination. Finally, "Made in Germany", which was striving for perfection, gained a worldwide reputation.

It can be seen that from the perspective of economic form and market development, from the home of traditional handicraft industry to the present Industry 4.0, the craftsmanship spirit has not withdrawn from the historical stage, but has become a spiritual power needed by all walks of life. Sorting out the historical evolution of craftsmanship spirit in Chinese vocational colleges can not only dig deep into the connotation of craftsmanship spirit, refine the law and trend of cultivating craftsmanship spirit, but also help to explore the contemporary value of craftsmanship spirit, optimize the path of cultivating and innovating craftsmanship spirit, and improve the fit between talent training and market demand in vocational colleges.

\section{THE HISTORICAL EVOLUTION OF CRAFTSMANSHIP SPIRIT IN VOCATIONAL COLLEGES}

In the 70 years since the founding of New China, vocational education has gone through a process from founding to reform and development, and its characteristic development. The value orientation and evaluation standard of talent training have been constantly adjusted with the economic environment, policy environment and industrial environment. The "Craftsmanship Spirit" has gone through a process from depression, exploration to development and revival in vocational colleges.

\section{A. The depression: a difficult start in the early days of the founding of the People's Republic of China}

In the early days of the founding of the People's Republic of China, the state developed vocational education according to the needs of economic construction. In the Common Program of the Chinese People's Political Consultative Conference in 1949, it was pointed out: "Pay attention to technical education, strengthen the amateur education of workers and the education of in-service cadres", which laid the policy foundation for the development of vocational education in China. The 156 key projects laid out in the first FiveYear Plan are the beginning of industrialization in New China. In order to train technical and technical talents needed to meet the key projects, the state has built a number of secondary technical schools and technical schools [2]. Vocational schools in this period have a natural connection with industrial enterprises. Based on the principle of "combining education with productive labor", enterprises affiliated to the labor department established and managed technical schools, trained skilled workers facing the front line of production, and strongly supported the industrial system construction in the early stage of the construction of New China.

Under the requirements of economic construction and rapid industrialization, the cultivation and development of craftsmanship spirit is in a downturn. On the one hand, the traditional handicraft industry has shrunk, the status of craftsmen is not high, and the craftsmanship spirit has not been well inherited and migrated; On the other hand, the pursuit of talent training efficiency and practicality, short training cycle, less teaching content, students quickly enter the workplace, entry standards are relatively loose, and the professionalism and professional attitude of craftsmen are not paid attention to.

Having higher professional skills is the solid foundation of craftsmanship spirit. During this period, the training of talents in vocational schools focused on connecting with practice, highlighting professional practical ability, and focusing on imparting professional technical skills in real labor production activities. However, there are no more requirements for students professional attitude and professional accomplishment, such as concentration, dedication, innovation, excellence and other spiritual elements. Nonetheless, on the basis of the special background of the times, a large number of technical backbones of national and local economic construction have been cultivated, which also laid the foundation for the development of vocational education. 


\section{B. The exploration: the adjustment and exploration after reform and opening-up}

During the "Cultural Revolution", vocational schools were regarded as the symbol of "the bourgeoisie's dual-track system", and a large number of them were closed down, merged or changed into ordinary middle schools. After the reform and openingup, the state shifted its focus to socialist modernization, and began to develop vocational education by adjusting the structure of secondary education, so as to train specialists and labor reserve forces for the change of economic structure. In 1985, the "Decision of the Central Committee of the Communist Party of China on the Reform of the Education System" proposed "gradually establishing a vocational and technical education system from primary to advanced, with supporting industries and reasonable structure, which can communicate with general education"; In 1991, the Decision of the State Council on Vigorously Developing Vocational and Technical Education pointed out that "we should actively promote the reform of existing vocational universities and strive to run a number of higher vocational schools that train highly skilled senior operators", which clearly defined the position and role of vocational education.

With the exploration of the socialist market economic system, vocational education at all levels has been restored and developed around the needs of building an open economic system. However, in the context of the pursuit of leapfrog development, the idea of quick success and instant benefit leads to the infinite expansion of the labor-intensive mode of production, and a big manufacturing country rather than a powerful manufacturing country is gradually formed [3]. In this process, the environment and institutional basis for inheriting and carrying forward the craftsmanship spirit have been neglected, and the soil for the growth of craftsmanship spirit has not been formed, such as the importance attached by the society to vocational education and the cultivation of students' craftsman consciousness by vocational education. After the reform of market economy system and state-owned enterprises, in order to reduce the historical burden of enterprises running the society, industrial enterprises have decoupled from vocational education. In addition, enterprises that are still in low-end production are unable to provide preferential treatment for skilled workers, and the attractiveness of vocational education has declined.

In 1990s, the national economic reform was further deepened, higher education was gradually transformed into civilian education, and secondary vocational school graduates were over-distributed from the national unity to self-employment. Facing the triple pressures of enrollment, teaching and employment, secondary vocational schools made adjustments and explorations in many aspects. In the exploration of adapting to the market economy and improving competitiveness, besides excellent professional skills, the professionalism, moral cultivation and ability evaluation required by the craftsmanship spirit are beginning to emerge in the talent training orientation.

\section{The development: vigorous reform at the turn of century}

In 1999, the Decision of the CPC Central Committee and the State Council on Deepening Education Reform and Promoting Quality Education in an All-round Way clearly stated for the first time: "Higher vocational education is an important part of higher education. We should vigorously develop higher vocational education and train a large number of specialized talents with necessary theoretical knowledge and strong practical ability, who are in urgent need of production, construction, management and service in the front line and in rural areas. "Since then, the number of higher vocational colleges in China has increased from dozens to more than 1,400, and China's vocational education has gradually grown into the largest vocational education system in the world.

In 2002, the State Council's "Decision on Vigorously Promoting the Reform and Development of Vocational Education" put forward "focusing on cultivating the professional skills, research spirit, pragmatic spirit, innovative spirit and entrepreneurial ability of the educated, and cultivating a large number of high-quality workers and practical talents who produce and serve the front line"; In 2005, the State Council's "Decision on Vigorously Developing Vocational Education" requires that "vocational education should serve to improve the quality of workers, especially their professional ability"; In 2008, the Ministry of Education's "Evaluation Plan for Talent Training in Higher Vocational Colleges" pointed out: "Promoting the connotation construction of higher vocational colleges and deepening the talent training mode of school-enterprise cooperation and work-study combination" can guide the reform and development of talent training mode and teaching practice in vocational colleges.

Since the 21st century, under the socialist market economic system, the reform of vocational education has continued to deepen, and the reform level has gone from macro policy making to micro education and teaching fields and school development capacity building. The direction of reform has changed from serving the needs of economy and society to the dual goals of people-oriented and meeting the all-round development of individuals and the needs of the market. Vocational colleges responded positively and vigorously carried out vocational education reform according to the training requirements of high-quality 
technical and technical talents, and put forward the concepts of "implementing quality education", "insisting on moral education first" and "cultivating high-quality labor force". Although the concept of "Craftsmanship Spirit" has not been clearly pointed out, it has strengthened the spiritual requirements in the school-running philosophy and development goals, and the connotation of craftsmanship spirit has gradually become prominent in the personnel training of vocational colleges, which has made an important historical contribution to China's transformation from a country with a large population to a country with large human resources.

\section{The revival: the revival of craftsmanship spirit in the new era}

The 18th National Congress of the Communist Party of China started a new journey of socialist modernization, and China became the second largest economy in the world. Facing the needs of industrial transformation and upgrading and high-quality economic development, vocational education has entered a characteristic development stage. In 2014, the State Council's "Decision on Accelerating the Development of Modern Vocational Education" proposed to "build a group of world-class vocational colleges and key majors to form an internationally competitive talent training highland"; In 2015, the Ministry of Education's Opinions on Deepening the Teaching Reform of Vocational Education and Improving the Quality of Talent Training in an Allround Way put forward that "higher vocational education should adhere to the connotative development path, strengthen ideological and moral education, humanistic quality education and technical skills training, and comprehensively improve the quality of talent training".

"Made in China 2025" clearly defined the goal of transforming from a big manufacturing country to a powerful manufacturing country. With the supply-side structural reform and the formation of five development concepts, "Craftsmanship Spirit" began to recover. Since the Government Work Report in 2016 put forward for the first time the idea of "cultivating the craftsmanship spirit of striving for perfection", "Craftsmanship Spirit" has been written into the Government Work Report for four consecutive years. In the report of the 19th National Congress of the Communist Party of China, it is proposed to "build an army of knowledge-based, skilled and innovative workers, carry forward the spirit of model workers and artisans, and create a glorious social fashion of labor and a professional atmosphere of striving for perfection". "Craftsmanship Spirit" began to be widely concerned by people, and quickly became the development criterion of manufacturing industry and even the value orientation of the whole society.
Vocational colleges provide technical and technical personnel support for the "Made in China 2025" strategy of strengthening the country, and must shoulder the mission of cultivating artisans' spirits. In 2017, the State Council's "Opinions on Deepening the Reform of Education System and Mechanism" emphasized that vocational education should improve the education mechanism of combining morality and technology with work and study, adhere to employment-oriented, and focus on cultivating students' craftsmanship, professional ethics, vocational skills and employment and entrepreneurship. ability; In 2019, the State Council's "National Vocational Education Reform Implementation Plan" pointed out that "developing higher vocational education is an important way to optimize the structure of higher education and train craftsmen and skilled craftsmen in big countries" and "cultivating and inheriting the craftsmanship spirit".

\section{THE CONTEMPORARY VALUE OF CRAFTSMANSHIP SPIRIT IN VOCATIONAL COLLEGES}

As China enters a new stage of development, the value of craftsmanship spirit has become increasingly prominent for vocational colleges.

\section{A. Inside: the craftsmanship spirit is an important focus for reform and development of vocational college}

Looking at the evolution of craftsmanship spirit in vocational colleges, we can see that craftsmanship spirit was gradually introduced by vocational colleges in the past 70 years to meet the needs of economic and market development. With the start, exploration, vigorous development and characteristic development of vocational education, the connotation of craftsmanship spirit has also experienced a process from initial appearance to manifestation. It can be said that craftsmanship spirit is an inevitable choice made by vocational colleges in the reform and innovation in order to maintain their unique position and characteristic development in the field of education.

Craftsmanship spirit injects rich ideological connotation into vocational education, which is the soul of "cultivating people by virtue" in vocational colleges. Craftsmanship spirit is also the spiritual benchmark of modern vocational education, which makes vocational colleges avoid the embarrassing position of training and producing "robots" and get rid of the misunderstanding of inferior education. Only when vocational colleges put their inheritance and innovation in a more prominent position in education reform and personnel training, can they enhance the humanistic value of vocational education from the root, promote the sustainable development of students, enhance the competitiveness of personnel training in vocational 
colleges and smoothly realize the modernization transformation.

\section{B. Outside: the craftsmanship spirit is an important guarantee for vocational colleges to meet the needs of economic and social talents}

At present, the industrial structure is upgraded, the manufacturing industry is moving towards the middle and high end, the new generation technologies such as $5 \mathrm{G}$ lead the scientific and technological revolution, and the grand blueprint of "Made in China 2025" has been rolled out. The transformation from a big manufacturing country to a powerful manufacturing country is based on the upgrading of technical and technical talents. However, there is still a shortage of 22 million senior technicians in China. In the past, "labor shortage" mainly refers to the shortage of workers with low technical threshold, but now it is highlighted by the lack of mature technicians. Many enterprises can't find suitable blue-collar talents even if they are hired with high salaries.

Nowadays, high-level vocational schools with Chinese characteristics and professional construction plans have been officially implemented, and the concept of talent training is jumping from single technical skills to "artisan-type" and "compound-type" talents. Craftsmen in big countries are the key to "China's intellectual creation". It is of great significance for vocational colleges to vigorously carry forward the craftsmanship spirit in the new era and cultivate highquality "craftsman-type" skilled talents and "compound" high-end talents, which will promote highquality economic development and achieve the two centenary goals.

\section{THE REALIZATION PATH AND COUNTERMEASURE OF CRAFTSMANSHIP SPIRIT IN VOCATIONAL COLLEGES}

At present, the state and society attach great importance to the craftsmanship spirit, creating a good public opinion environment for the cultivation of the craftsmanship spirit. Vocational colleges should seize the "east wind" of the strong return of craftsmanship spirit, transform the understanding of craftsmanship spirit into actions at the executive level, and fully realize and innovate the value of craftsmanship spirit in personnel training.

\section{A. Constructing the craftsmanship spirit training curriculum system}

Classroom teaching is the most direct way for students to learn skills and accomplishments [4]. Only by constructing the curriculum system of cultivating craftsmanship spirit can we avoid the blindness of cultivating craftsmanship spirit and fill the blank of cultivating craftsmanship spirit in vocational colleges. On the one hand, vocational colleges should pay more attention to the humanities general education course, and set up public courses such as "Craftsmanship Spirit", "History of Industrial Civilization", "Foundation of Innovation and Entrepreneurship" and "Career Planning" in combination with the actual situation, and formulate a teaching curriculum plan suitable for the cultivation of craftsmanship spirit. Strengthen students' awareness of craftsmanship spirit; On the other hand, it is necessary to fully integrate the craftsmanship spirit into the existing professional courses, so that the craftsmanship spirit runs through the course teaching, especially paying attention to making students feel in practical courses, and integrating the professional spirit, professional norms and professional ethics of counterpart industries into students' behaviors and attitudes.

\section{B. Strengthening industry-education integration and school-enterprise cooperation}

The integration of production and education and school-enterprise cooperation are the lifeline of vocational education, and also an important carrier for cultivating craftsmanship spirit [5]. First, vocational colleges should actively build a platform for schoolenterprise collaborative innovation[6], give full play to the advantages of modern apprenticeship system, deepen the reform of talent training mode of workstudy combination, realize the dual-subject education of schools and enterprises, establish master studios and famous teacher studios, and realize the omni-directional guidance of "teachers + masters"; second, it is necessary to strengthen the construction of training bases, integrate the relevant forces of government, banks, enterprises and schools, run schools in industrial functional areas, move schools into parks, set classrooms in factory areas, give full play to the effectiveness of enterprise management, and achieve accurate docking between teaching and production processes; third, it is important to make full use of international resources, implement international cooperation projects, carry out the localization practice of international talent training standards, introduce international assessment and certification, form an international talent training system, promote the docking of curriculum content with international standards, and stimulate the new kinetic energy of craftsmanship spirit cultivation.

\section{Building a campus culture with the craftsmanship spirit as the main line}

Cultural education exerts a subtle influence on teachers' and students' ideology, morality, values and behavior habits in a way of group culture. First of all, vocational colleges should integrate the connotation of craftsmanship and dedication into the school motto, and 
explicitly include "promoting craftsmanship spirit" and "cultivating big country craftsmen" into the school goals and development orientation, creating glorious labor, precious skills and creating a great campus culture. atmosphere; Secondly, we must form a "Craftsmanship Spirit" cultivation system that combines professionalism and industrial civilization, organically integrate industrial culture, corporate culture and industry culture, and create "ingenuity training" brand activities such as "Industrial Culture Festival" and "big country craftsmen entering the campus". Make use of professional skills competitions, community activities, etc., let the craftsmanship spirit penetrate into the daily campus study and living environment; In addition, we should build campus culture with the inheritance of industrial culture as the main line, build an open Expo, school history museum and experience area, and carry out industrial culture popularization and scientific research activities.

\section{CONCLUSION}

In September 2019, when General Secretary Xi Jinping inspected Shandan Peili School in Zhangye City, he emphasized: "China's economy depends on the real economy, which requires a large number of professional and technical talents and a large number of craftsmen from big countries. Therefore, vocational education is promising. Building a manufacturing power is an opportunity for vocational education to make great achievements, while inheriting and innovating craftsmanship spirit is the strategic basis and inexhaustible motive force for vocational colleges to make great achievements in the new era.

\section{References}

[1] Li Guolan. Analysis of the evolution and development of craftsmanship spirit [J]. Vocational Education Research, 2018(04): 14-17.

[2] Guo Wenfu, Ma Shuchao. Historical characteristics and experience of vocational education development since the founding of New China 70 years ago [J]. Education and Occupation, 2019(19): 5-10.

[3] Zhen Min. "Made in China" from the perspective of vocational colleges craftsmanship spirit training strategy research [D]. Hunan Normal University, 2017.

[4] Li Guolan. Research on Cultivation of Craftsmanship Spirit of Higher Vocational College Students [D]. Shenyang Normal University, 2018.

[5] Li Jin. Research report on the effect of local regulations on regional vocational education $[\mathrm{J}]$. Chinese vocational and technical education, 2016: 59-62.

[6] Chen Chunmin. Study on the Contemporary Value of "Craftsmanship Spirit" and Its Cultivation Path [D]. Central China Normal University, 2018. 